\title{
Migratory crustaceans as biomonitors of metal pollution in their nursery areas. The Lesina lagoon (SE Italy) as a case study
}

\author{
R. D'Adamo • M. Di Stasio • A. Fabbrocini • \\ F. Petitto $・$ L. Roselli $\cdot$ M. G. Volpe
}

Received: 29 March 2007 / Accepted: 27 August 2007

(C) Springer Science + Business Media B.V. 2007

\begin{abstract}
The Lesina lagoon is located on the southern Adriatic coast of Italy; many marine species, such as the shrimp M. kerathurus, use the Lesina lagoon as a nursery, spending their initial growth phase there. In order to assess the usefulness of migratory species as biomonitors of the environmental quality of this nursery area, we evaluated the metal content of the M. kerathurus juveniles at the end of their growth phase in the lagoon (October), when they are assumed to have bioaccumulated the maximum level of metals from the lagoon environment. The concentrations of $\mathrm{Cr}, \mathrm{Cd}, \mathrm{Pb}, \mathrm{Zn}, \mathrm{Mn}$ and $\mathrm{Cu}$ were measured in the muscle and exoskeleton of the shrimp, and in the sediments and waters of three areas of the Lesina Lagoon. Both the water and sediment levels of the investigated metals tended to fall within the ranges recorded for other lagoon environments characterized by similar anthropic impact and texturally similar sediment; the juveniles of the shrimp M. kerathurus proved to be strong
\end{abstract}

R. D'Adamo · A. Fabbrocini $(\bowtie) \cdot$ L. Roselli

Consiglio Nazionale delle Ricerche -

Istituto di Scienze Marine,

via Pola 4,

71010 Lesina (FG), Italy

e-mail: adele.fabbrocini@fg.ismar.cnr.it

M. Di Stasio - F. Petitto - M. G. Volpe

Consiglio Nazionale delle Ricerche -

Istituto di Scienze dell'Alimentazione,

via Roma 52 a/c,

83100 Avellino, Italy bioaccumulators of heavy metals such as $\mathrm{Zn}$ and $\mathrm{Cu}$ (biota-sediment accumulation factors - BSAFs - 6.01 and 25.0 respectively), which derive from agricultural activities; therefore, at the end of their growing phase in the lagoon they can be considered useful biomonitors of metal contamination of agricultural origin in their nursery area.

Keywords Heavy metals · Bioaccumulation · Biomonitor · Shrimp juveniles $\cdot$ Sediment .

Lesina lagoon

\section{Introduction}

Lagoon ecosystems are biotopes of great ecological value, due to their high biodiversity; moreover, they are economically important because of fishing and aquaculture (Vazquez et al. 1999). Agricultural, urban and industrial inputs may cause high levels of contamination within these ecosystems; for this reason there is a need for tailored monitoring programs to identfy ecosystem changes in relation to environmental alterations (Magni 2003).

Sediments represent one of the main sinks for toxic substances in such ecosystems; in addition, toxicants coming from the catchment area are transported to the lagoon by drainage during the rainfall.

Toxicants coming from the drainage basin and those released due to resuspension of sediments, can affect both benthic and pelagic organisms (Volpi Ghirardini 
et al. 1999), which bioaccumulate them mainly through the food chain (Sfriso et al. 1995; Ip et al. 2005). The combination of many factors such as the shallowness of the water column, the limited exchange of waters with the sea, the large fluctuations in physical and chemical parameters, and the heterogeneous processes at the interface between dissolved phase and suspended particulate matter can enhance the impact of pollutant inputs, especially trace elements, on the biota (Cognetti and Maltagliati 2000; Censi et al. 2006).

Heavy metals within coastal lagoons are of special concern: they may be of both agricultural or industrial origin, are highly phytotoxic and can alter the primary productivity of the environment. Aquatic organisms bioaccumulate metals mainly by the food pathway, but also through direct adsorption on the body surface (Boisson et al. 2003). Therefore these organisms can be used to assess the presence of toxicants such as metals in the habitats in which they live.

The use of biomonitor species in assessing environmental contaminant levels has proven to be a valuable approach, and is now recognized worldwide. Useful biomonitor organisms should concentrate target contaminants, and be sessile or sedentary and widely distributed; bivalves are the most commonly used biomonitors, but also macroalgae, echinoderms, crustaceans and fish are also employed widely (Sfriso et al. 1995; Warnau et al. 1995; Guhathakurta and Kaviraj 2000; Catsiki and Florou 2006; Hedouin et al. 2006).

The Lesina lagoon is one of the main nursery areas of the southern Adriatic coast; the limited tidal influence, the lack of water stratification due to the shallowness, and the high water residence times (Ficca et al. 1995; Manini et al. 2002) may led to accumulation in the ecosystem of toxicants coming from the drainage basin.

The penaeid shrimp Melicertus kerathurus (Forskál 1775 ) is one of the most common among the species using the Lesina Lagoon as a nursery ground: juveniles of $M$. kerathurus migrate from the Adriatic sea to the Lesina lagoon in June-July, attracted by the high food availability they need for growing; from early autumn, when the temperature rapidly decreases, adults migrate back to the sea or die, as they cannot survive the low water temperatures in winter (D'Adamo et al. 2007; Lumare et al. 1996). Many authors have demonstred that the human impact on the nursery areas (from both human activity discharges and fishing) strongly affect recruitment level and population size (Johnson et al. 1998; Le Pape et al. 2003).

The aim of the present study was to estimate the bioaccumulation of selected heavy metals in the juveniles (mean length $7 \mathrm{~cm}$ ) of the penaeid shrimp Melicertus kerathurus (Forskál 1775), and the relative concentrations in the waters and sediments of the Lesina lagoon. The sampling was carried out in the early autumn, when the drainage is at a maximum due to the peak in rainfall. This species was selected as a possible biomonitor for many reasons: M. kerathurus uses the Lesina lagoon as a nursery, spending its initial growth phase in the lagoon and increasing the body size from about $5 \mathrm{mg}$ to $5 \mathrm{~g}$ from June to October (Lumare et al. 1996); shrimps accumulate heavy metals mainly from the food pathway (Boisson et al. 2003); metal bioaccumulation is known to be higher in juveniles as a consequence of their higher metabolic activity (Páez-Osuna and Ruiz-Fernández 1995a; Hedouin et al. 2006). For these reasons, in early autumn, in the Lesina lagoon ecosystem, they can be assumed to have bioaccumulated the maximum level of metals from the lagoon environment. Thus, although some decapods are known to regulate the internal concentration of some metals (Phillips 1990), M. kerathurus in this case and in this life stage was considered to be a possible biomonitor for its nursery area.

\section{Materials and methods}

Study area

The Lesina Lagoon (Fig. 1) is located on the southern Adriatic coast of Italy (Puglia region) on the northern side of the Gargano promontory ( $41^{\circ} 51^{\prime} 47^{\prime \prime}-41^{\circ} 54^{\prime}$ $40^{\prime \prime} \mathrm{N}$ and $\left.15^{\circ} 18^{\prime} 48^{\prime \prime}-15^{\circ} 34^{\prime} 28^{\prime \prime} \mathrm{E}\right)$. It is a brackish basin (0.7-1.5 $\mathrm{m}$ deep) separated from the sea by a 1-2 $\mathrm{km}$ wide dunal cordon and connected to the sea through two channels, Schiapparo and Acquarotta. It stretches for about $22 \mathrm{~km}$ along an East-West axis and is $3 \mathrm{~km}$ wide, covering an area of $51 \mathrm{~km}^{2}$, with a volume of $41.2 \times 10^{6} \mathrm{~m}^{3}$. Precipitation is limited (400-700 mm year) and follows a strong seasonal pattern with the lowest levels in the summer and the main rainfall period in September (data from the 


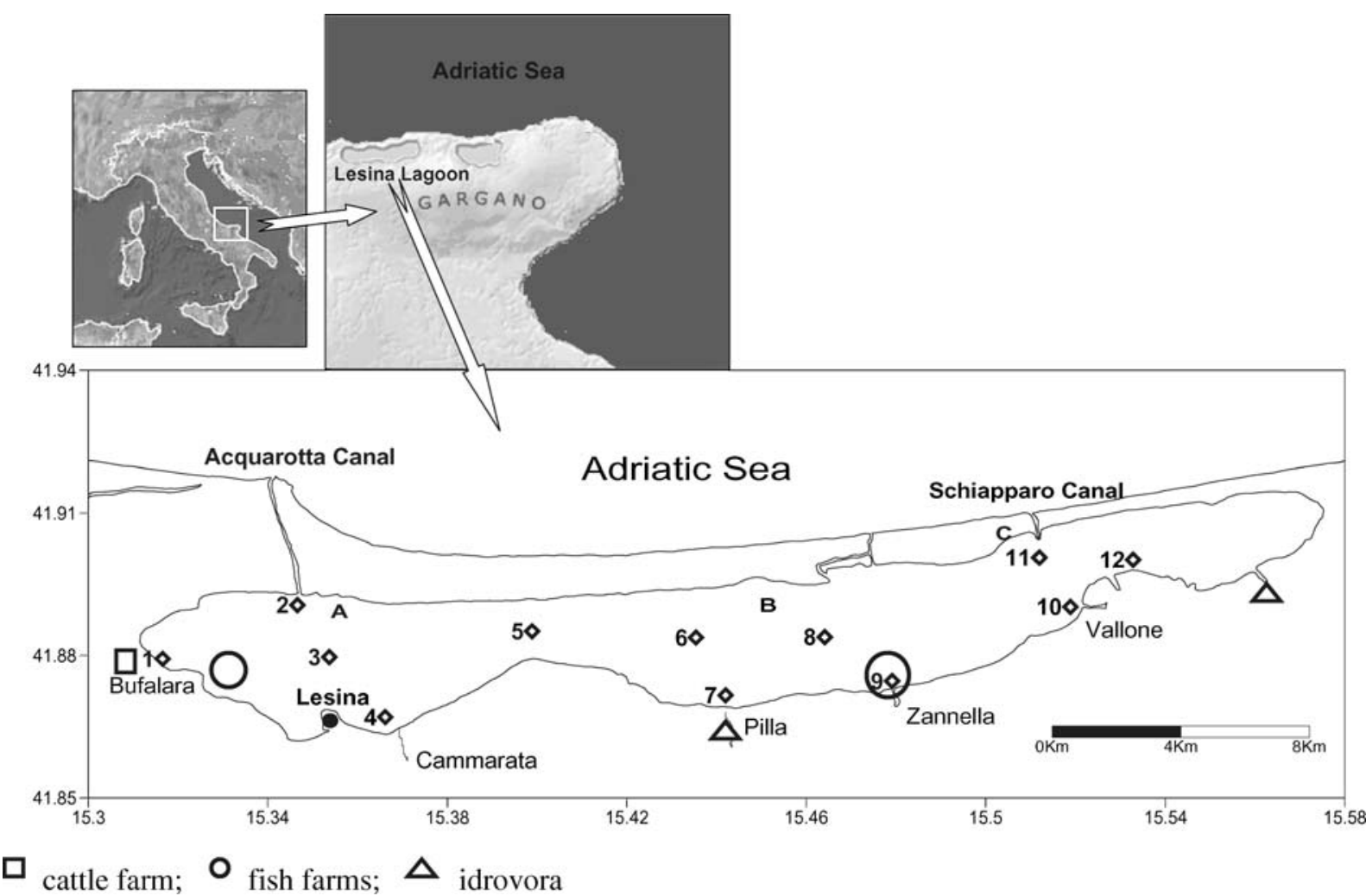

Fig. 1 Position of the Lesina lagoon along Adriatic coastline and details of sampling sites and of the various agricultural, zootechnical and urban discharges

Consorzio di Bonifica di Capitanata, Foggia, Italy); the freshwater input mainly derives from small seasonal rivers, the Pilla and Zanella springs and the Lauro Canal (Manini et al. 2002). A numerical study taking into account the tidal and wind forcing shows that the tidal range is attenuated with respect to the sea tide, and that due to the limited depth the decay time is three to five cycles only, i.e the water residence time is about 70-100 days (Ficca et al. 1995).

Salinity levels show interannual, seasonal, and spatial variations, with a tendency to increase from the western basin to the eastern basin, depending on the rainfall and water evaporation rates, values ranging from 3 to 44 psu (Manini et al. 2003; Fabbrocini et al. 2005).

The drainage basin of the Lesina lagoon is about $600 \mathrm{~km}^{2}$; it is used mostly for agriculture $(21,000$ ha of cereals and vegetable crops); onshore there are also two fish farms and a livestock farm; three towns, with a total of about 30,000 inhabitants, release urban waste into the lagoon from two sewage treatment plants.
The bottom sediments are characterised by a high organic matter content ( $8-15 \%)$; the main granulometric class $(>90 \%)$ is the silty-clay fraction $(<63 \mu \mathrm{m})$, with a large quantity of biogenic deposits (Fabbrocini et al. 2005). Zoostera noltii and Ruppia cirrhosa are the most abundant macrophytobentos species in the western and central-eastern basin respectively. Macrozoobenthos mainly consists of mussels, anellida and crustaceans (Nonnis-Marzano et al. 2003).

\section{Sample collection}

Samplings were carried out during the first ten days of October 2004 in twelve sampling sites (Fig. 1), after the main rainfall period had drained the agricultural residues coming from the summer crop treatments, and at the end of the shrimps' initial growth phase. Water samples (sites 1-2-4-6-10-11) were collected, at a depth of $30 \mathrm{~cm}$ in a Niskin bottle, acidified with $\mathrm{HNO}_{3} \quad 0.5 \%$ and stored in neutral polyethylene bottles. Salinity was recorded using a multiparametric 
probe (YSI 556MPS). The first $5 \mathrm{~cm}$ of surface sediment were collected in triplicate in sites 1 to 12 by pole core (internal diameter $4.5 \mathrm{~cm}$, surface area $15 \mathrm{~cm}^{2}$ ), placed in polyethylene flasks and immediately transferred on ice to the laboratory; the three replicates were then mixed, homogenized and stored at $-20^{\circ} \mathrm{C}$. Shrimp juveniles (mean length rostrumtelson extreme $7.19 \pm 0.68 \mathrm{~cm}$; mean weight $2.95 \pm$ $0.8 \mathrm{~g})$ were collected by fyke nets and gill nets located in the three lagoon areas (sites A-B-C). Individuals were immediately rinsed with lagoon water, wrapped in polyethylene bags, and transferred on ice to the laboratory. Three pools, each containing 15 specimens randomly selected, were created; the exoskeleton was then removed and the muscle was cut into pieces; all the samples were stored in polyethylene bags at $-20^{\circ} \mathrm{C}$.

Heavy metal content evaluation

Heavy metal analyses were performed according to established procedures described in Avella et al. (2005) and in Bruno et al. (2006).

Shrimps: For both muscle and exoskeleton, three grams of sample were placed in a china crucible, weighed and heated in a furnace at $105^{\circ} \mathrm{C}$ until constant weight (about $12 \mathrm{~h}$ ); the sample was then cooled for $30 \mathrm{~min}$ in dry air and weighed again (approximation $1 \mathrm{mg}$ ). Moisture was calculated as the difference between initial and final weight of samples. The sample was carbonated over a small flame, placed in a muffle furnace at $700^{\circ} \mathrm{C}$ for a few hours, cooled in dry air for $30 \mathrm{~min}$ and weighed again (approximation $1 \mathrm{mg}$ ). Ash content was calculated as the difference between initial and final weight. The obtained ashes were dissolved in $10 \mathrm{ml}$ of hydrochloric acid solution, warmed in a hot water bath and then filtered. Distilled water was added up to $50 \mathrm{ml}$ and the sample underwent heavy metal content evaluation.

Sediments: Three aliquots of sediment (2 $\mathrm{g}$ each) were digested in hydrochloric acid solution for 24 hours. After centrifugation for $17 \mathrm{~min}$ at $4500 \mathrm{rpm}$, the supernatant was filtered through a $0.45 \mu \mathrm{m}$ filter, distilled water was added up to $50 \mathrm{ml}$ and the sample underwent heavy metal content evaluation.

Water samples were acidified with $5 \% \mathrm{HNO}_{3}$, then filtered through a $0.45 \mu \mathrm{m}$ filter and directly analysed.

A Spectrophotometer (Varian - SpectrAA 200, Mulgrave - Victoria, Australia) was used, together with a flame burner and a Varian GTA-100 graphite furnace atomizer. The Flame AA burner was used for determining manganese (waters and sediments), chromium, copper (sediments), zinc, lead (sediments) and cadmium (sediments) content, and the graphite furnace AA atomizer for lead (waters and shrimps), cadmium (waters and shrimps), copper (waters and shrimps), and manganese (shrimps).

Analyses were run in triplicate and the following detection limits were employed:

Sediments: $\mathrm{Pb}(5-15 \mu \mathrm{g} / \mathrm{g}) ; \mathrm{Cr}(5-15 \mu \mathrm{g} / \mathrm{g}) ; \mathrm{Cd}$ (1-3 $\mu \mathrm{g} / \mathrm{g}) ; \mathrm{Zn}(2-6 \mu \mathrm{g} / \mathrm{g}) ; \mathrm{Cu}(3-9 \mu \mathrm{g} / \mathrm{g}) ; \mathrm{Mn}$ (5-15 $\mu \mathrm{g} / \mathrm{g})$

Waters: $\mathrm{Pb}(10-30 \mu \mathrm{g} / \mathrm{L}) ; \mathrm{Cr}(0.2-1.0 \mathrm{mg} / \mathrm{L}) ; \mathrm{Cd}$ $(5-15 \mu \mathrm{g} / \mathrm{L}) ; \mathrm{Zn}(2-6 \mathrm{mg} / \mathrm{L}) ; \mathrm{Cu}(10-30 \mu \mathrm{g} / \mathrm{L})$; $\mathrm{Mn}(0.5-1.5 \mathrm{mg} / \mathrm{L})$

Shrimps: $\mathrm{Pb}(10-30 \mu \mathrm{g} / \mathrm{g}) ; \mathrm{Cr}(2-10 \mu \mathrm{g} / \mathrm{g}) ; \mathrm{Cd}$ $(0.5-1.5 \mu \mathrm{g} / \mathrm{g}) ; \mathrm{Zn}(5-15 \mu \mathrm{g} / \mathrm{g}) ; \mathrm{Cu}(10-30 \mu \mathrm{g} / \mathrm{g})$; Mn $(5-15 \mu \mathrm{g} / \mathrm{g})$

The standard deviation was always lower than $1 \%$ for flame atomic absorption spectrometry and 5\% for atomic absorption spectrometry with the graphite furnace.

Statistical analyses

Statistical analyses were carried out using the Statistica 7.0 statistical package (Statsoft inc., Tulsa, OK, USA). One-way analyses of variance (ANOVA) were used to investigate differences between the four analysed matrices (sediment, water, muscle and exoskeleton).

The biota-sediment accumulation factors (BSAFs) of each metal were calculated according to the formula: $\mathrm{BSAF}=\mathrm{Cx} / \mathrm{Cs}$, where $\mathrm{Cx}$ and $\mathrm{Cs}$ are the mean concentrations of metal in the shrimp muscle and the associated sediment respectively (Soto-Jimenéz et al. 2001; Szefer et al. 1999).

\section{Results}

Concentrations of the investigated metals $(\mathrm{Cd}, \mathrm{Pb}$, $\mathrm{Cu}, \mathrm{Mn}, \mathrm{Zn}$ and $\mathrm{Cr}$ ) in samples of water, sediment and shrimps collected from the study area are presented in Tables 1, 2 and 3. 
Table 1 Salinity and concentrations of cadmium $(\mathrm{Cd})$, lead $(\mathrm{Pb})$, copper $(\mathrm{Cu})$, manganese $(\mathrm{Mn})$, zinc $(\mathrm{Zn})$ and chromium $(\mathrm{Cr})$ in water $\left(\mu \mathrm{g} \mathrm{l}^{-1}\right)$ at various sampling sites in the Lesina lagoon

\begin{tabular}{llllllll}
\hline Stations & Salinity $(\mathrm{psu})$ & $\mathrm{Cd}(\mathrm{mean} \pm \mathrm{SD})$ & $\mathrm{Pb}(\mathrm{mean} \pm \mathrm{SD})$ & $\mathrm{Cu}($ mean $\pm \mathrm{SD})$ & $\mathrm{Mn}($ mean $\pm \mathrm{SD})$ & $\mathrm{Zn}(\mathrm{mean} \pm \mathrm{SD})$ & $\mathrm{Cr}(\mathrm{mean} \pm \mathrm{SD})$ \\
\hline 1 & 22.23 & $4.99 \pm 0.94$ & $21.02 \pm 0.26$ & $10.38 \pm 1.06$ & $36.50 \pm 3.54$ & $0.06 \pm 0.05$ & $95.00 \pm 7.94$ \\
2 & 22.91 & $0.74 \pm 0.08$ & $25.65 \pm 0.45$ & $8.87 \pm 0.97$ & $18.00 \pm 3.46$ & $0.08 \pm 0.04$ & $84.67 \pm 7.57$ \\
4 & 21.75 & $18.54 \pm 3.45$ & $42.93 \pm 0.68$ & $15.10 \pm 2.21$ & $35.33 \pm 3.51$ & $46.97 \pm 1.30$ & $84.33 \pm 6.03$ \\
6 & 16.29 & $7.84 \pm 1.18$ & $42.83 \pm 0.53$ & $14.83 \pm 1.84$ & $17.00 \pm 1.41$ & $0.07 \pm 0.11$ & $69.00 \pm 7.00$ \\
10 & 12.66 & $0.20 \pm 0.05$ & $8.64 \pm 0.16$ & $12.31 \pm 0.80$ & $13.00 \pm 2.83$ & $34.03 \pm 1.52$ & $38.67 \pm 1.53$ \\
11 & 14.08 & $3.88 \pm 0.25$ & $17.94 \pm 1.22$ & $16.43 \pm 2.01$ & $74.33 \pm 1.15$ & $8.30 \pm 0.87$ & $97.67 \pm 5.03$ \\
\hline
\end{tabular}

Water

Salinity levels (Table 1) ranged from $9.84 \mathrm{psu}$ (sampling site 12) to $22.91 \mathrm{psu}$ (sampling site 2).

All six metals were found in all the sampling sites, although the amounts were negligible in some cases, $\mathrm{Cr}$ and $\mathrm{Pb}$ being the most abundant (Table 1). The distribution of $\mathrm{Cu}\left(8-16 \mu \mathrm{g} \mathrm{l}^{-1}\right), \mathrm{Cr}\left(38-95 \mu \mathrm{g} \mathrm{l}^{-1}\right)$ and $\mathrm{Mn}\left(13-74 \mu \mathrm{g} \mathrm{l}^{-1}\right)$ was more or less homogeneous across sampling sites, and the main source of these metals could not be identified; conversely, $\mathrm{Pb}$ $\left(8-42 \mu \mathrm{g} 1^{-1}\right), \mathrm{Cd}\left(0.2-18 \mu \mathrm{g} \mathrm{l^{-1 }}\right)$ and $\mathrm{Zn}(0.06-46 \mu \mathrm{g}$ $\left.1^{-1}\right)$ were found in higher concentrations near discharges from urban, livestock and agricultural sources, while in the other sampling sites levels they were near the minimum necessary for analytical detection.

Sediments

The distribution in the sediment (Table 2) of Cd (0.4 $\left.1.3 \mu \mathrm{g} \mathrm{g}^{-1}\right)$ and $\mathrm{Mn}\left(63-160 \mu \mathrm{g} \mathrm{g}^{-1}\right)$ was homogeneous across sampling sites and the main source of these metals could not be identified; $\mathrm{Cr}\left(0.4-31 \mu \mathrm{g} \mathrm{g}^{-1}\right)$ and Zn (2-23 $\left.\mu \mathrm{g} \mathrm{g}^{-1}\right)$ were mainly recorded near the mouths of the channels, while $\mathrm{Pb}\left(0.6-28 \mu \mathrm{g} \mathrm{g}^{-1}\right)$ and $\mathrm{Cu}\left(0.4-14 \mu \mathrm{g} \mathrm{g}^{-1}\right)$ were found mainly in the central area of the lagoon and near the points of entry of urban and agricultural runoff.

\section{Shrimps}

Measured concentrations of the six investigated metals in the exoskeleton and muscle of M. kerathurus were broadly similar across sampling sites. $\mathrm{Zn}$ was the most abundant element detected, ranging from 40 to $60 \mu \mathrm{g} \mathrm{g}^{-1}$ in both exoskeleton and muscle. $\mathrm{Cr}$ also showed similar levels for exoskeleton (3-5 $\mu \mathrm{g} \mathrm{g}^{-1}$ ) and muscle $\left(2-10 \mu \mathrm{g} \mathrm{g}^{-1}\right)$, comparable to those of the sediments. The highest concentrations of $\mathrm{Cu}$ were recorded in the exoskeleton (39-60 $\mathrm{gg} \mathrm{g}^{-1}$ ), which proved to bioaccumulate this metal at up to five times the concentration of either muscle (6-26 $\left.\mu \mathrm{g} \mathrm{g}^{-1}\right)$. Conversely, the lowest bioaccumulation in shrimp tissues was recorded for $\mathrm{Mn}\left(0.7-13 \mu \mathrm{g} \mathrm{g}^{-1}\right.$ in the

Table 2 Concentrations of cadmium $(\mathrm{Cd})$, lead $(\mathrm{Pb})$. copper $(\mathrm{Cu})$, manganese $(\mathrm{Mn})$, zinc $(\mathrm{Zn})$ and chromium $(\mathrm{Cr})$ in sediment $\left(\mu \mathrm{g} \mathrm{g}^{-1}\right.$ dry weight) at various sampling sites in the Lesina lagoon

\begin{tabular}{lllllll}
\hline Stations & $\mathrm{Cd}(\mathrm{mean} \pm \mathrm{SD})$ & $\mathrm{Pb}(\mathrm{mean} \pm \mathrm{SD})$ & $\mathrm{Cu}(\mathrm{mean} \pm \mathrm{SD})$ & $\mathrm{Mn}(\mathrm{mean} \pm \mathrm{SD})$ & $\mathrm{Zn}(\mathrm{mean} \pm \mathrm{SD})$ & $\mathrm{Cr}(\mathrm{mean} \pm \mathrm{SD})$ \\
\hline 1 & $0.46 \pm 0.19$ & $1.64 \pm 0.26$ & $2.24 \pm 0.59$ & $100.08 \pm 30.74$ & $12.69 \pm 1.31$ & $7.71 \pm 1.71$ \\
2 & $0.66 \pm 0.13$ & $5.36 \pm 0.50$ & $3.02 \pm 0.63$ & $153.20 \pm 26.54$ & $23.57 \pm 3.17$ & $13.39 \pm 3.21$ \\
3 & $0.79 \pm 0.06$ & $12.05 \pm 0.56$ & $6.26 \pm 1.45$ & $126.35 \pm 14.69$ & $14.39 \pm 1.91$ & $18.18 \pm 0.32$ \\
4 & $0.84 \pm 0.05$ & $8.08 \pm 4.36$ & $11.25 \pm 0.57$ & $160.52 \pm 1.01$ & $15.58 \pm 3.51$ & $17.22 \pm 0.22$ \\
5 & $1.01 \pm 0.29$ & $27.49 \pm 7.57$ & $4.16 \pm 0.05$ & $107.99 \pm 8.59$ & $10.01 \pm 1.07$ & $10.12 \pm 0.17$ \\
6 & $0.77 \pm 0.06$ & $6.29 \pm 0.78$ & $1.93 \pm 1.24$ & $102.47 \pm 0.26$ & $6.59 \pm 3.00$ & $6.28 \pm 0.15$ \\
7 & $0.44 \pm 0.10$ & $21.87 \pm 0.24$ & $8.04 \pm 2.26$ & $96.72 \pm 10.82$ & $11.55 \pm 2.53$ & $11.34 \pm 5.44$ \\
8 & $1.16 \pm 0.03$ & $28.34 \pm 1.46$ & $1.90 \pm 1.24$ & $143.64 \pm 0.95$ & $8.05 \pm 5.27$ & $11.76 \pm 0.13$ \\
9 & $0.85 \pm 0.07$ & $8.47 \pm 0.77$ & $14.37 \pm 2.43$ & $135.32 \pm 8.90$ & $23.88 \pm 6.44$ & $31.07 \pm 7.67$ \\
10 & $0.84 \pm 0.25$ & $21.33 \pm 5.98$ & $1.67 \pm 1.43$ & $156.13 \pm 0.84$ & $17.36 \pm 0.02$ & $18.54 \pm 0.20$ \\
11 & $0.68 \pm 0.40$ & $1.32 \pm 1.11$ & $0.42 \pm 0.19$ & $63.61 \pm 0.39$ & $2.73 \pm 0.63$ & $0.45 \pm 0.14$ \\
12 & $1.34 \pm 0.19$ & $0.63 \pm 0.72$ & $0.68 \pm 0.03$ & $92.78 \pm 57.98$ & $13.07 \pm 0.29$ & $2.92 \pm 1.65$ \\
\hline
\end{tabular}


Table 3 Concentrations of cadmium $(\mathrm{Cd})$, lead $(\mathrm{Pb})$, copper $(\mathrm{Cu})$, manganese $(\mathrm{Mn})$, zinc $(\mathrm{Zn})$ and chromium $(\mathrm{Cr})$ in tissues of Melicerthus kerathurus ( $\mu \mathrm{g} \mathrm{g}^{-1}$ dry weight) taken from various sampling sites in the Lesina lagoon

\begin{tabular}{lllllll}
\hline Stations & $\mathrm{Cd}(\mathrm{mean} \pm \mathrm{SD})$ & $\mathrm{Pb}(\mathrm{mean} \pm \mathrm{SD})$ & $\mathrm{Cu}($ mean $\pm \mathrm{SD})$ & $\mathrm{Mn}($ mean $\pm \mathrm{SD})$ & $\mathrm{Zn}(\mathrm{mean} \pm \mathrm{SD})$ & $\mathrm{Cr}(\mathrm{mean} \pm \mathrm{SD})$ \\
\hline Muscle & & & & & & \\
$\mathrm{A}$ & $0.10 \pm 0.08$ & $0.47 \pm 0.04$ & $14.90 \pm 0.06$ & $0.99 \pm 0.13$ & $41.83 \pm 11.91$ & $1.88 \pm 0.06$ \\
$\mathrm{~B}$ & $0.16 \pm 0.11$ & $0.68 \pm 0.32$ & $6.60 \pm 0.03$ & $4.99 \pm 2.65$ & $49.62 \pm 1.17$ & $4.30 \pm 0.29$ \\
$\mathrm{C}$ & $0.23 \pm 0.02$ & $0.64 \pm 0.19$ & $26.00 \pm 0.13$ & $1.84 \pm 0.41$ & $60.37 \pm 14.84$ & $4.25 \pm 0.19$ \\
Exoskeleton & & & & & \\
A & $2.04 \pm 0.25$ & $2.37 \pm 0.34$ & $57.94 \pm 6.58$ & $13.34 \pm 2.14$ & $46.35 \pm 0.42$ & $3.08 \pm 0.09$ \\
B & $2.93 \pm 0.34$ & $5.74 \pm 1.03$ & $47.58 \pm 3.17$ & $12.31 \pm 0.43$ & $59.30 \pm 3.62$ & $4.96 \pm 0.16$ \\
$\mathrm{C}$ & $0.91 \pm 0.74$ & $1.83 \pm 0.66$ & $39.18 \pm 7.61$ & $13.85 \pm 0.92$ & $56.45 \pm 5.28$ & $3.45 \pm 0.21$ \\
\hline
\end{tabular}

exoskeleton and $0.2-5 \mu \mathrm{g} \mathrm{g}^{-1}$ in muscle). $\mathrm{Pb}$ and $\mathrm{Cd}$ were the least abundant metals, ranging from 0.2 to $5 \mu \mathrm{g} \mathrm{g}^{-1}$ and from 0.2 to $2 \mu \mathrm{g} \mathrm{g}^{-1}$ respectively in the exoskeleton, and from 0.4 to $1 \mu \mathrm{g} \mathrm{g}^{-1}$ and from 0.07 to $0.2 \mu \mathrm{g} \mathrm{g}^{-1}$ respectively in the muscle; their concentrations were lower than or comparable to those recorded in the sediments.

Table 4 summarizes the results of statistical analyses.

The one-way ANOVA shows that sediments always bioconcentrate metals $(P<0.01)$ at significantly higher levels than the water. $\mathrm{Cd}, \mathrm{Mn}$ and $\mathrm{Zn}$ are always higher in shrimp tissues than in sediments $(P<$ $0.001)$, while $\mathrm{Pb}$ and $\mathrm{Cr}$ concentrations are comparable. Lastly, bioaccumulation levels in the exoskeleton are significantly higher $(P<0.001)$ than in the muscle, except for $\mathrm{Zn}$ and $\mathrm{Cr}$, where they are comparable.

As shown in Fig. 2, the BSAF values for $\mathrm{Cd}, \mathrm{Pb}$, $\mathrm{Mn}$ and $\mathrm{Cr}$ are always less than one; in contrast $\mathrm{Cu}$ and $\mathrm{Zn}$ have BSAF levels ranging from 1.76 to 25 , and from 2.20 to 6.01 respectively; in addition, the concentrations of these two metals in the muscle of M. kerathurus juveniles are negatively correlated with salinity $(r=-0.32$ for $\mathrm{Cu}$ and $r=-0.93$ for $\mathrm{Zn}$, respectively), the higher BSAF values being recorded for shrimps coming from the $\mathrm{C}$ site, characterized by the lowest salinity levels.

\section{Discussion and conclusions}

The metal content of the Lesina lagoon sediments recorded in this study is in good agreement with data reported by other authors in the same area (Table 5) specifically, these values are comparable to those of the contiguous Varano lagoon (Spagnoli et al. 2002) and to those recorded along the southern Adriatic coast (Storelli et al. 2001). In addition, it is important to point out that they are similar to those of lightly impacted areas of the Venice lagoon (e.g. the Treporti station, Volpi Ghirardini et al. 1999), and lower than those recorded in strongly anthropized areas of both the Venice lagoon (e.g. the Marghera station, Volpi Ghirardini et al. 1999) and Goro Bay (Locatelli and Torsi 2002). They are also similar to those recorded for other lagoon environments characterized by a similar anthropic impact and a texturally similar sediment (Cheggour et al. 2001; Chen 2002).

Table 4 Probabilities ( $P$ values) from one-way ANOVA analysis

\begin{tabular}{|c|c|c|c|c|c|c|}
\hline $\begin{array}{l}\text { Heavy } \\
\text { Metal }\end{array}$ & $\begin{array}{l}\text { Sediment vs } \\
\text { water }\end{array}$ & $\begin{array}{l}\text { Sediment vs } \\
\text { muscle }\end{array}$ & $\begin{array}{l}\text { Sediment vs } \\
\text { exoskeleton }\end{array}$ & $\begin{array}{l}\text { Water vs } \\
\text { muscle }\end{array}$ & $\begin{array}{l}\text { Water vs } \\
\text { exoskeleton }\end{array}$ & $\begin{array}{l}\text { Muscle vs } \\
\text { exoskeleton }\end{array}$ \\
\hline $\mathrm{Cd}$ & $<0.001$ & $<0.001$ & 0.002 & $<0.001$ & 0.001 & 0.037 \\
\hline $\mathrm{Pb}$ & 0.012 & n.s. & n.s & $<0.001$ & 0.004 & n.s \\
\hline $\mathrm{Cu}$ & 0.022 & n.s. & $<0.001$ & 0.005 & $<0.001$ & $<0.001$ \\
\hline $\mathrm{Mn}$ & $<0.001$ & $<0.001$ & $<0.001$ & 0.014 & $<0.001$ & 0.001 \\
\hline $\mathrm{Zn}$ & $<0.001$ & $<0.001$ & $<0.001$ & $<0.001$ & $<0.001$ & n.s \\
\hline $\mathrm{Cr}$ & 0.002 & n.s. & n.s & $<0.001$ & $<0.001$ & n.s \\
\hline
\end{tabular}

$\mathrm{P}$ values are considered significant when lower than 0.05 (n.s. = not significant) 
Fig. 2 Bio-sediment accumulation factor $(B S A F)$ values calculated for selected metals in the M. kerathurus muscle

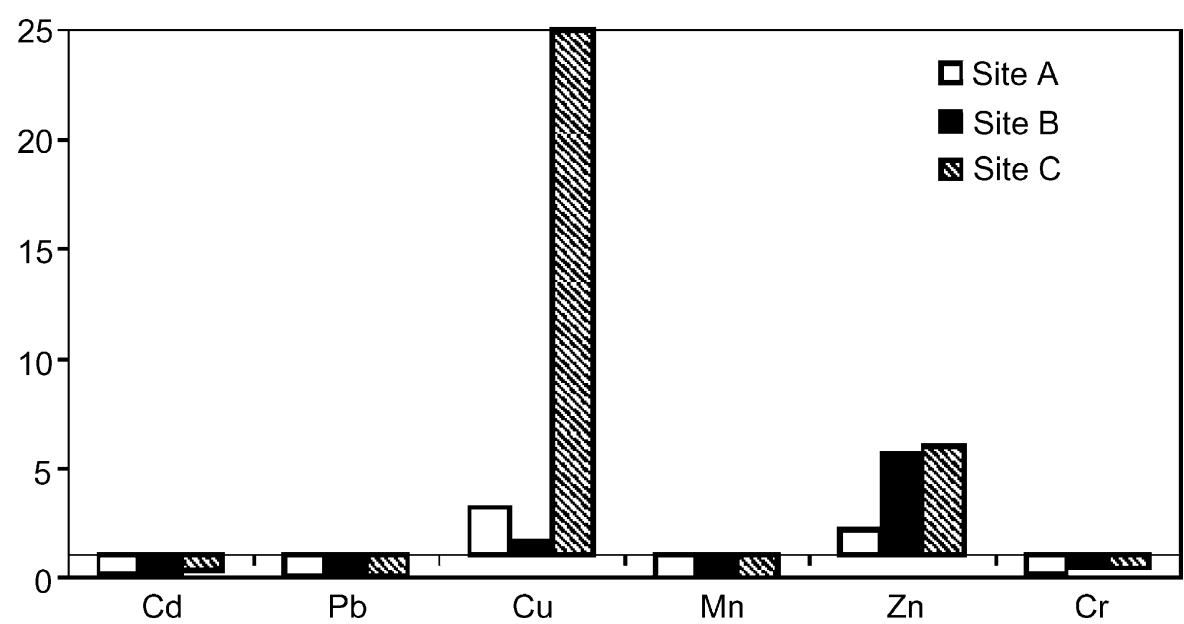

Previous studies carried out on the sediments of the Lesina Lagoon (De Benedictis 1997) reported levels of $\mathrm{Cd}\left(0.5-0.9 \mu \mathrm{g} \mathrm{g}^{-1}\right)$ and $\mathrm{Cu}\left(2-25.5 \mu \mathrm{g} \mathrm{g}^{-1}\right)$ similar to those recorded in this study, showing that they have not changed markedly in the last decade, while $\mathrm{Zn}$ levels $\left(255-1,155 \mu \mathrm{g} \mathrm{g}^{-1}\right)$ have considerably decreased. It should be noted, however, that variables other than the variation of the inputs, such as salinity, redox conditions, and resuspension by wind-driven waves, may affect metal levels in lagoon sediments (Marcomini et al. 1993; Vazquez et al. 1999; Bellucci et al. 2002). The metal content of the sediments proved to be $10^{2}-10^{3}$ times that of the water, whose values are again lower than or similar to those recorded by other authors for similar environments (Vazquez et al. 1999; Chou et al. 2004). Mn displayed the highest concentration factor in sediment (3,000 times the value recorded in the water), followed by $\mathrm{Zn}(1,600 \times), \mathrm{Pb}$ and $\mathrm{Cu}(500 \times)$.
Although a relationship between salinity and some metal levels in the water has been reported for lagoon and estuarine environments characterized by a wide salinity range (Vazquez et al. 1999; Wang and Liu 2003), the concentrations of all the investigated metals in the sampled sites of the Lesina lagoon, where a marked salinity trend has not been recorded, were found to be independent of salinity.

A study carried out on the eel Anguilla anguilla in the Lesina lagoon (Storelli et al. 2007) showed that the heavy metal content of the eels did not exceed the maximum levels fixed by the European Commission. Metal levels in $M$. kerathurus were again lower than or comparable to those recorded in shrimp juveniles from similar environments, the exoskeleton displaying higher bioaccumulation $(3-12 \times)$ than muscle (Paez Osuna and Tron-Mayen 1996; Guhathakurta and Kaviraj 2000; Chou et al. 2004). High Cu and Zn levels in muscle and high $\mathrm{Cd}, \mathrm{Cu}$ and $\mathrm{Zn}$ levels in the

Table 5 Range or mean \pm S.D. of metal concentrations in sediments ( $\mu \mathrm{g} \mathrm{g}^{-1}$ dry weight) in the Lesina lagoon and in other sites along the Adriatic Coast

\begin{tabular}{lllllll}
\hline Metals & $\begin{array}{l}\text { Lesina } \\
\text { lagoon } \\
\text { (this study) }\end{array}$ & $\begin{array}{l}\text { Varano lagoon } \\
\text { (Spagnoli et al. } \\
\text { 2002) }\end{array}$ & $\begin{array}{l}\text { Venice - Treporti } \\
\text { (Volpi G. et al. } \\
1999)\end{array}$ & $\begin{array}{l}\text { Venice - Marghera } \\
\text { (Volpi G. et al. } \\
1999)\end{array}$ & $\begin{array}{l}\text { Goro Bay } \\
\text { (Locatelli and Torsi } \\
2002)\end{array}$ & $\begin{array}{l}\text { South Adriatic Sea } \\
\text { (Storelli et al. } \\
2001)\end{array}$ \\
\hline $\mathrm{Cd}$ & $0.44-1.34$ & $0.95 \pm 0.76$ & 0.17 & 12.30 & $0.14-0.69$ & $0.13-0.24$ \\
$\mathrm{~Pb}$ & $0.63-28.34$ & $40.95 \pm 26.16$ & 10.5 & 70.0 & $3.91-6.69$ \\
$\mathrm{Cu}$ & $0.42-14.37$ & $12.27 \pm 8.9$ & 12.7 & 116.4 & $13.39-20.18$ \\
$\mathrm{Mn}$ & $63.61-153.20$ & - & 273.0 & 533.0 & - \\
$\mathrm{Zn}$ & $2.73-23.88$ & - & 47.0 & 3513.0 & - & 51.6 \\
$\mathrm{Cr}$ & $0.45-31.07$ & $28.85 \pm 18.06$ & 37.0 & 59.0 & -80.3 & -151.2 \\
\hline
\end{tabular}


exoskeleton were recorded, up to two to four times those of the sediments; however, relatively high concentrations of metals such as $\mathrm{Zn}$ and $\mathrm{Cu}$ in crustacean tissues are routinely reported by many authors, and are attributed to the role they play as activators of numerous enzymes (Depledge et al. 1993; Paez-Osuna and Tron-Mayen 1996). The concentrations of heavy metals in the tissues of marine invertebrates mainly depend on the accumulation strategy adopted for each metal, and result from the net difference between rates of uptake and excretion of the metals, which in turn are affected by factors such as the nature of the food, the permeability of the animal's external surface, and the efficiency of osmoregulation and detoxification systems such as metallothioneins (Moksnes et al. 1995; Paez-Osuna and Ruiz-Fernández 1995b). Both shrimp tissues, as recorded for most marine organisms (Rainbow and Phillips 1993), were found to bioaccumulate the investigated metals at higher concentrations than in the water; furthermore, the high BSAF values for $\mathrm{Zn}$ and $\mathrm{Cu}$ highlight the ability of $M$. kerathurus juveniles to bioaccumulate copper and zinc in their soft tissues. It is important to point out that these two metals are present in the pesticides commonly used in the catchment area of the Lesina lagoon (Franchi and Pelosi 1998). The markedly higher BSAF levels recorded for both metals in the shrimps from station $\mathrm{C}$ suggest greater metal bioavailability due to the different salinity levels (Mubiana et al. 2005; Speelmans et al. 2007); however, different food types occurring in the three areas may also partly explain this difference.

In conclusion M.kerathurus juveniles, despite their recognized capacity for regulating the tissue concentrations of particular metals (by means of osmoregulation, detoxification, moultings) proved to be strong bioaccumulators of heavy metals such as $\mathrm{Zn}$ and $\mathrm{Cu}$, which derive from agricultural activities; therefore, at the end of their growing phase in the lagoon, juveniles of the shrimp M. kerathurus can be considered, useful biomonitors of metal contamination of agricultural origin in their nursery area.

Acknowledgements This research was supported by EU-POR (Regional Operative Program) Puglia Regional Grant 20002006. The authors wish to thank two anonymous referees for their constructive criticism of the manuscript.

\section{References}

Avella, M., De Vlieger, J. J., Errici, M. E., Fischer, S., Vacca, P., \& Volpe, M. G. (2005). Biodegradabile starcy/clay nanocomposites for food packaging applications. Food Chemistry, 93, 467-474.

Bellucci, L. G., Frignani, M., Paolucci, D., \& Ravanelli, M. (2002). Distribution of heavy metals in sediments of the Venice Lagoon: the role of the industrial area. The Science of the Total Environment, 295, 35-49.

Boisson, F., Cotret, O., Teyssié, J. L., El-Baradei, M., \& Fowler, S. W. (2003). Relative importance of dissolved and food pathways for lead contamination in shrimp. Marine Pollution Bulletin, 46, 1549-1557.

Bruno, G., Volpe, M. G., De Luise, G., \& Paolucci, M. (2006). Detection of heavy metals in farmed Cherax destructor. Bulletin of Fr. Pêche et Pisciculture, 380-381, 1341-1350.

Catsiki, V. A., \& Florou, H. (2006). Study on the behaviour of the heavy metals $\mathrm{Cu}, \mathrm{Cr}, \mathrm{Ni}, \mathrm{Zn}, \mathrm{Fe}, \mathrm{Mn}$ and ${ }^{137} \mathrm{Cs}$ in an estuarine ecosystem using Mytilus galloprovincialis as a bioindicator species: the case of Thermaikos gulf, Greece. Journal of Environmental Radioactivity, 86, 31-44.

Censi, P., Spoto, S. E., Saiano, F., Sprovieri, M., Mazzola, S., \& Tardone, G., et al. (2006). Heavy metals in coastal water systems. A case study from the northwestern Gulf of Thailand. Chemosphere, 64, 1167-1176.

Cheggour, M., Chafik, A., Langston, W. J., Burt, G. R., Benbrahim, S., \& Texier, H. (2001). Metals in sediments and the edible cockle Cerastoderma edule from two Moroccan Atlantic lagoons: Moulay Bou Selham and Sidi Moussa. Environmental Pollution, 115, 149-160.

Chen, H. M. (2002). Baseline metal concentrations in sediment and fish, and the determination of bioindicators in the subtropical Chi-ku lagoon, S.W. Taiwan. Marine Pollution Bulletin, 44, 703-714.

Chou, C. L., Paon, L. A., Moffatt, J. D., Buzeta, M. I., Fenton, D., \& Rutherford, R. J. (2004). Distribution of contaminants in biota and sediments in the Musquash Estuary, Atlantic Canada, marine protected area site initiative and contaminant exclusion zone. Marine Pollution Bulletin, 48, 884-893.

Cognetti, G., \& Maltagliati, F. (2000). Biodiversity and adaptive mechanisms in brackish water fauna. Marin Pollution Bulletin, 40, 7-14.

D’Adamo, R., Deolo, A., Maselli, M. A., \& Fabbrocini, A. (2007). Characterization of the stock of the penaeid shrimp Melicertus kerathurus in a Mediterranean coastal lagoon (Lesina Lagoon, Southern Italy). Paper presented at the 41st European Marine Biology Society Congress, Cork (EIRE), September.

De Benedictis, A. (1997). Studio sulla distribuzione spaziale e temporale di alcuni metalli pesanti nella laguna di Lesina. Bollettino di Informazione del CNR-ISEC, 1997, Lesina, Foggia, Italy (in Italian).

Depledge, M. H., Forbes, T. L., \& Forbes, V. E. (1993). Evaluation of Cadmium, Copper, Zinc and Iron concentrations and tissue distribution in the benthic crab, Dorippe granulata (De Haan, 1841) from Tolo Harbour, Hong Kong. Environmental Pollution, 81, 15-19.

Fabbrocini, A., Guarino, A., Scirocco, T., Franchi, M., \& D'Adamo, R. (2005). Integrated biomonitoring assessment 
of the Lesina Lagoon (Southern Adriatic Coast, Italy): Preliminary results. Chemistry \& Ecology, 21(6), 479-489.

Ficca, G., Pierini, S., \& Purini, R. (1995). Numerical study of the dynamics of a lagoon. Paper presented at the 2nd International Conference on the Mediterranean Coastal Environment, Tarragona (Spain), October.

Franchi, M., \& Pelosi, S. (1998). Impatto delle attività agricole sulla laguna di Lesina. Terra Pugliese, 47(2), 17-21 (in Italian).

Guhathakurta, H., \& Kaviraj, A. (2000). Heavy metal concentration in water, sediment, shrimp (Penaeus monodon), and mullet (Liza parsia) in some brackish water ponds of Sunderban, India. Marine Pollution Bulletin, 40(11), 914-920.

Hédouin, L., Metian, M., Teyssié, J. L., Fowler, S. W., Fichez, R., \& Warnau, M. (2006). Allometric relationships in the bioconcentration of heavy metals by the edible tropical clam Gafrarium tumidum. Science of the Total Environment, 366, 154-163.

Ip, C. C. M., Li, X. D., Zhang, G., Wong, C. S. C., \& Zhang, W. L. (2005). Heavy metal and Pb isotopic composition of aquatic organisms in the Pearl River Estuary, South China. Environmental Pollution, 138, 495-505.

Johnson, L. L., Landahl, J. T., Kubin, L. A., Horness, B. H., Myers, M. S., \& Collier, T. K., et al. (1998). Assessing the effects of anthropogenic stressors on Puget Sound flatfish populations. Journal of Sea Research, 39, 125-137.

Le Pape, O., Holley, J., Guérault, D., \& Désaunay, Y. (2003). Quality of coastal and estuarine essential fish habitats: Estimations based on the size of juvenile common sole (Solea solea L.). Estuarine, Coastal and Shelf Science, 58, 793-803.

Locatelli, C., \& Torsi, G. (2002). A new voltammetric method for the simultaneous monitoring of heavy metals in sea water, sediments, algae and clams: Application to the Goro Bay ecosystem. Environmental Monitoring and Assessment, 75, 281-292.

Lumare, F., Scordella, G., Zonno, V., Di Muro, P., Tessarin, C., \& Zanella, L. (1996). Morphometric study of the wild population of Penaeus kerathrus, Forskäl 1775, from Aquatina and Lesina lagoons (south-east Italian coast). Oebalia, 22, 57-64.

Magni, P. (2003). Biological benthic tools as indicators of coastal marine ecosystems health. Chemistry and Ecology, 19(5), 363-372.

Manini, E., Breber, P., D’Adamo, R., Spagnoli, F., \& Danovaro, R. (2002). Lagoon of Lesina. Land-Ocean interactions in the coastal zone (LOICZ). Nutrient fluxes in transitional zones of the Italian coast: A Report of the LaguNet Workshop. LOICZ Reports \& Studies; pp. 49-54.

Manini, E., Fiordelmondo, C., Gambi, C., Pusceddu, A., \& Danovaro, R. (2003). Benthic microbial loop functioning in coastal lagoons: a comparative approach. Oceanologica Acta, 26, 27-38.

Marcomini, A., Sfriso, A., \& Zanette, M. (1993).Macroalgal blooms, nutrient and trace metal cycles in a coastal lagoon. In: J. W. Rijstenbil \& S. Haritonidis. Bridge DG XII Report, CEC, Brussels, Belgium 1993.

Moksnes, P. O., Lindhal, U., \& Haux, C. (1995). Metallothionein as a bioindicator of heavy metal exposure in the tropical shrimp Penaeus vannamei: A study of dosedependent induction. Marine Environmental Research, 39, 143-146.
Mubiana, V. K., Qadah, D., Meys, J., \& Blust, R. (2005). Temporal and spatial trends in heavy metal concentrations in the marine mussel Mytilus edulis from the Western Scheldt estuary (The Netherlands). Hydrobiologia, 540, 169-180.

Nonnis-Marzano, C., Scalera-Liaci, L., Fianchini, A., Gravina, F., Mercurio, M., \& Corriero, G. (2003). Distribution, persistence and change in the macrobenthos of the lagoon of Lesina (Apulia, southern Adriatic Sea. Oceanologica Acta, 26, 57-66.

Páez-Osuna, F., \& Ruiz-Fernández, C. (1995a). Trace metals in the Mexican shrimp Penaeus vannamei from estuarine and marine environments. Environmental Pollution, 87, 243247.

Páez-Osuna, F., \& Ruiz-Fernández, C. (1995b). Comparative bioaccumulation of trace metals in Penaeus stylirostris in estuarine and coastal environments. Estuarine, Coastal and Shelf Science, 40, 35-44.

Páez-Osuna, F., \& Tron-Mayen, L. (1996). Concentration and distribution of heavy metals in tissues of wild and farmed shrimp Penaeus vannamei from the north-west coast of Mexico. Environmental International, 22(4), 443-450.

Phillips, D. J. H. (1990). Use of macroalgae and invertebrates as monitors of metal levels in estuaries and coastal waters. In R. W. Furness, \& P. S. Rainbow (Eds.) Heavy metals in the marine environment (pp. 81-96). Florida, USA: CRC Press.

Rainbow, P. S., \& Phillips, D. J. H. (1993). Cosmopolitan biomonitors of trace metals. Marine Pollution Bulletin, 26, 593-601.

Sfriso, A., Marcomini, A., \& Zanette, M. (1995). Heavy metals in sediments, SPM and phytozoobenthos of the Lagoon of Venice. Marine Pollution Bulletin, 30(2), 116-124.

Soto-Jiménez, M. F., Páez-Osuna, F., \& Morales-Hernández, F. (2001). Selected trace metals in oysters (Crassostrea iridescens) and sediments from the discharge zone of the submarine sewage outfall in Mazatlán Bay (Southeast Gulf of California): Chemical fractions and bioaccumulation factors. Environmental Pollution, 114, 357-370.

Spagnoli, F., Specchiulli, A., Scirocco, T., Carapella, G., Villani, P., \& Casolino, G., et al. (2002). The lago di Varano: Hydrologic characteristics and sediment composition. Marine Ecology, 23(1), 384-394.

Speelmans, M., Vanthyne, D. R. J., Lock, D., Hendrickx, F., Du, L. G., \& Tack, F. M. G., et al. (2007). Influence of flooding, salinity and inundation time on the bioavailability of metals in wetlands. Science of the Total Environment, 380, 144-153.

Storelli, M. M., Barone, G., Garofalo, R., \& Marcotriggiano, G. O. (2007). Metals and organochlorine compounds in eel (Anguilla anguilla) from the Lesina lagoon, Adriatic Sea (Italy). Food Chemistry, 100, 1337-1341.

Storelli, M. M., Storelli, A., \& Marcotriggiano, G. O. (2001). Heavy metals in the aquatic environment of the Southern Adriatic Sea, Italy. Macroalgae, sediments and benthic species. Environment International, 26, 505-509.

Szefer, P., Ali, A. A., Ba-Haroon, A. A., Rajeh, A. A., Geldon, J., \& Nabrzyski, M. (1999). Distribution and relationships of selected trace metals in mollusks and associated sediments from the gulf of Aden, Yemen. Environmental Pollution, 106, 299-314. 
Vazquez, G. F., Sharma, V. K., Magallanes, V. R., \& Marmolejo, A. J. (1999). Heavy metals in a coastal lagoon of the Gulf of Mexico. Marine Pollution Bulletin, 38(6), 479-485.

Volpi Ghirardini, A., Birkemeyer, T., Arizzi Novelli, A., Delaney, E., Pavoni, B., \& Ghetti, P. F. (1999). An integrated approach to sediment quality assessment: the Venetian lagoon as a case study. Aquatic Ecosystem Health \& Management, 2, 435-447.
Wang, Z. L., \& Liu, C. Q. (2003). Distribution and partition behaviour of heavy metals between dissolved and acidsoluble fractions along a salinity gradient in the Changjiang Estuary, eastern China. Chemical Geology, 202, 383-396.

Warnau, M., Ledent, G., \& Tempra, A. (1995). Allometry of heavy metal bioconcentration in the echinoid Paracentrotus lividus. Archives of Environmental Contamination and Toxicology, 29, 393-399. 